\title{
Effect of growth and cultivar on alfalfa digestibility in a multi-site trial
}

\author{
B Julier*, C Huyghe \\ Station d'amélioration des plantes fourragères, Inra, 86600 Lusignan, France
}

(Received 19 August 1997; accepted 20 November 1997)

\begin{abstract}
Summary - It is well known that digestibility decreases during growth in alfalfa (Medicago sativa $\mathrm{L}$ ), but the effects of genetic variation and the environment on digestibility are less documented. Seven cultivars were studied in five locations in France, and four samplings were taken over two regrowth cycles. Forage yield, stem height, number of stems, plant digestibility, stem digestibility and leaf/stem ratio were recorded. All traits were influenced by location, cycle, cultivar and sampling date effects. Digestibility decreased with yield, as plants grew, and leaf/stem ratio also decreased. The regression between plant digestibility and yield was the same for all the cultivars. However, this regression was quite different depending on the location. Digestibility decreased faster in some locations than in others. Location effects were not related to average temperatures. The seven cultivars showed differences in digestibility, as a result of various combinations of leaf/stem ratio and stem digestibility. At harvest time (beginning of flowering), no correlation between yield and digestibility was observed, showing that it was possible to identify high yielding and digestible varieties.
\end{abstract}

\section{Medicago sativa $\mathrm{L}=$ alfalfa / digestibility / forage / genetic variation / growth}

Résumé - Effet de la croissance et du génotype sur la digestibilité de la luzerne dans un essai multilocal. Il est bien connu que la digestibilité de la luzerne (Medicago sativa $\mathrm{L}$ ) diminue au cours de la croissance, mais la variabilité génétique et l'effet du milieu sur la digestibilité sont moins documentés. Sept génotypes ont été étudiés en cinq lieux en France, et quatre prélèvements ont été effectués au cours de deux cycles de repousse. Le rendement en fourrage, la hauteur, le nombre de tiges, la digestibilité de la plante entière, la digestibilité des tiges et le rapport feuilles-tiges ont été mesurés. Tous les caractères sont influencés par le lieu, le cycle de repousse, le génotype et la date de prélèvement. Au cours d'un cycle, la digestibilité de la plante entière et des tiges, et le rapport feuilles/tiges décroissent avec le rendement. La régression entre la digestibilité de la plante entière et le rendement est la même pour tous les génotypes étudiés. Cependant, cette régression est différente selon les lieux, la digestibilité diminue plus rapidement dans certains lieux que dans d'autres. Mais l'effet du lieu n'est pas relié à sa température moyenne. Les différences que montrent les sept génotypes pour la digestibilité résultent de différentes combinaisons de rapports feuilles/tiges et de digestibilités de tiges. Ces deux caractères doivent être mesurés pour permettre de progresser plus rapidement sur la digestibilité de la plante entière. Au moment de la récolte (début floraison), il n'y avait pas de corrélation entre rendement et digestibilité, ce qui montre la possibilité d'identifier des variétés à la fois productives et digestibles.

Medicago sativa $\mathrm{L}=$ luzerne / croissance / digestibilité / fourrage / variabilité génétique

Article communicated by Michael Hayward (Aberystwyth)

* Correspondence and reprints

Tel: 05495560 38; fax: 0549556044 ; e-mail: julier@lusignan.inra.fr 


\section{INTRODUCTION}

Cultivation of alfalfa in France has dramatically decreased over the past 30 years. The use of this forage crop for highly productive cattle is limited because of its low energetic value. However, alfalfa remains an attractive crop because of agronomic advantages such as protein content, yield and perenniality. Breeding programs nowadays focus on the energetic value of alfalfa. Alfalfa intake is quite high compared to that of grasses, but forage digestibility is low (Andrieu et al, 1988). However, two alfalfa cultivars, differing for digestibility, induced differences in milk production of dairy cows (Emile et al, 1996, 1997). Genetic variation for digestibility in alfalfa has been shown (Heinrichs et al, 1969; Buxton et al, 1987; Lenssen et al, 1991; Julier et al, 1996), and possibilities for improving populations have been demonstrated (Demment et al, 1986). Some data are available on changes in digestibility during plant growth. Plant digestibility decreases as the plant grows because: i) leaf/stem ratio decreases and leaves are more digestible than stems; and ii) stem digestibility decreases during growth (Terry and Tilley, 1964; Mowat et al, 1965; Heinrichs et al, 1969). Kalu and Fick (1983) proposed a mean stage index linked to digestibility and fibre content. Onstad and Fick (1983) found that, in one location, sums of growing degree-days are useful for predicting stem digestibility during growth. Lemaire and Allirand (1993) proposed an equation between digestibility and aerial dry matter. For five cultivars in a range of environments, height of the tallest stem and maturity stage of the most mature stem were the best predictors of fiber contents (Hintz and Albrecht, 1991). In addition to effects of growth, the evaluation of the digestibility of a cultivar is difficult because of year, cycle, location effects and their interactions. The effects of temperature (Vough and Marten, 1971) and water stress (Carter and Sheaffer, 1983; Deetz et al, 1996), which are part of environmental variation, on digestibility have been described under controlled conditions. The global effect of the environment on digestibility is not well described.

The objective of this study was to evaluate and compare the digestibility of several cultivars during their growth in several locations and for two growing cycles. The importance of some morphological traits for plant digestibility was assessed.

\section{MATERIAL AND METHODS}

Seven cultivars were studied. Europe, Maya and Luzelle are French varieties of Flemish type; Lodi is an
Italian variety, of Mediterranean type; Julus is a Swedish variety, and Natsuwakaba is a Japanese variety, both of Flemish type. The experimental cultivar 63-28P, selected at Inra Lusignan, showed a higher digestibility in previous experiments (Émile and Traineau, 1993).

These cultivars were sown in six locations in France, in collaboration with the breeding companies of the Association des créateurs de variétés fourragères: Cappelle-en-Pévèle (Nord) by Florimond-Desprez, Connantre (Marne) by Barenbrug-Tourneur, Les Alleuds (Maine-et-Loire) by Limagrain, VerneuilL'Étang (Seine-et-Marne) by GIE Recherche VerneuilSemunion, and Montpellier (Hérault) and Lusignan (Vienne) by Inra. The trials were sown in 1994 in each location except at Lusignan where the cultivars were sown in 1992, in a randomized block design with four replicates. Plots were sown at $20 \mathrm{~kg} / \mathrm{ha}$ density, with rows $0.14-0.25 \mathrm{~m}$ apart depending on the location.

For four cultivars (Europe, Maya, 63-28P and Lodi), four samples were taken during each of the first two growing cycles of 1995, except at Lusignan where only the first cycle was analysed. Samplings were made on $0.17-0.25-\mathrm{m}^{2}$ sub-plots depending on the location. The sampling dates were chosen according to the phenological stage of Europe: canopy height of $0.20,0.40$ and $0.60 \mathrm{~m}$, and beginning of flowering. Maya followed the same phenological development as Europe, but Lodi and 63-28P had a 5-day delay for the beginning of flowering. The samples were taken on different plots for the two cycles. On the other three varieties, only the last sampling was made.

The plant height was measured on the plots, and on each sample, the number of stems and the forage dry matter were recorded. The distribution of the stem heights in $0.10-\mathrm{m}$ classes was analysed. The average height of the stems (mean of the heights weighted by the number of stems per class) was calculated. On one block per sampling date and for all cultivars, leaves and stems were separated, and weighed separately to determine leaf/stem ratio. All the samples were ground ( $1 \mathrm{~mm}$ grid), and analysed by near infrared spectroscopy. On 127 samples, the enzymatic digestibility (Lila et al (1986) method with only pepsin and cellulases) was manually determined. These digestibilities were used to build an equation of prediction of digestibility by NIRS. The coefficient of correlation between prediction and manual measurements was 0.98 and standard error of cross-validation was 1.56. The leaf/stem ratio was also predicted by NIRS, using an equation calibrated on previous trials, and validated with the 179 values obtained in this trial. The coefficient of correlation was 0.84 and the standard error of validation was 0.32 . Leaf/stem ratios higher than 1.8 were under-estimated, but within the range of $0.5-1.8$, prediction was accurate.

Stem digestibility (Sdig) was calculated from whole plant digestibility (Pdig) and leaf/stem ratio (LS), using a leaf digestibility of $90 \%$. Leaf digestibility was proved to be constant over growth and for various cultivars (Terry and Tilley, 1964; Mowat et al, 1965; Heinrichs et al, 1969): 


$$
\operatorname{Sdig}=(\operatorname{Pdig}+90 /(1+1 / \mathrm{LS})) \times(\mathrm{LS}+1)
$$

Stem yield was also calculated from plant yield and leaf/stem ratio.

On all traits, analyses of variance were performed to test location, cultivar, sampling date, cycle and block effects, and their interactions. Data from Les Alleuds were discarded because of excessive missing values. Correlations between traits were calculated. Similar analyses were made on the samples harvested at beginning of flowering. In order to analyse the effect of location on digestibility, the average temperature in each location for each cycle was calculated for the last 4 weeks before final harvest (beginning of flowering of cv Europe).

\section{RESULTS}

\section{Analysis of growth effect}

Results of analysis of variance for the four cultivars at different sampling dates in two cycles are presented in table I. For all morphological traits (plant height and mean stem height, yield, number of stems and leaf/stem ratio), location, cycle and sampling date were the most important effects. Almost all interactions were significant. For all traits including digestibility, the cultivar effect was significant.

Correlations between morphological traits were similar to those already reported for alfalfa (table II). Leaf/stem ratio was negatively correlated with forage yield, stem yield, plant height and mean stem height. Forage yield was correlated with plant height and mean stem height but independent of number of stems. Plant digestibility was negatively correlated with forage yield, plant height and mean stem height. It was positively correlated with leaf/stem ratio, and weakly correlated with number of stems. Stem digestibility was correlated with plant digestibility, stem yield and heights.

In alfalfa production, the two interesting characters are forage yield and plant digestibility. Digestibility decreased linearly with forage yield (fig 1). This relationship was modelled with the linear model: digestibility $=a+b \times$ yield. The parameters are presented in table III for the four cultivars and the five locations. No cultivar had statistically different intercepts and regression slopes from the global regression with all cultivars. The five locations behaved differently. Digestibility was fairly constant as yield increased at Montpellier. It decreased more quickly but had a higher intercept at Lusignan and Verneuil than at Connantre and Cappelle.

\section{Analysis at harvest time}

For all traits, analysis of variance showed location, cycle and cultivar effects (table IV). The interaction between location and cycle was significant, but the other interactions were either barely significant or not significant. Location effect was higher than cycle effect, except for plant digestibility, forage yield and stem number for which they were similar.

Some correlations that were significant considering the variations due to growth (table IV) became non-significant at harvest time (table V), such as plant digestibility with forage yield, stem digestibility with stem yield, stem digestibility with stem and plant heights. Plant digestibility was correlated with leaf/stem ratio, stem digestibility, stem and plant heights. Leaf/stem ratio and stem digestibility were not correlated. Forage and stem yields were correlated with height.

The mode of comparison of different cultivars for digestibility is a problem considering the effect of growth on digestibility. In our study, harvesting was carried out when the cultivars Europe and Maya began to flower, but the other varieties had a less advanced phenological stage. Average plant digestibility, stem digestibility, leaf/stem ratio and yield are presented in table VI. Natsuwakaba appeared to be the least digestible, with a low stem digestibility but a high leaf/stem ratio. 63-28P had the highest digestibility as the result of high leaf/stem ratio and high stem digestibility. The other five varieties had rather similar digestibilities, achieved with high leaf/stem ratio (as Lodi) or high stem digestibility (as Europe).

Mean digestibility, forage yield and average temperature over the last 4 weeks before harvest in each location for each cycle are presented in table VII. No correlation can be seen between average temperature and average plant digestibility.

\section{DISCUSSION}

Considering the regrowth period, significant effects of location, cycle, cultivar and sampling date were observed for morphological and digestibility traits. Although these effects are quite well known for morphological traits and yield on 


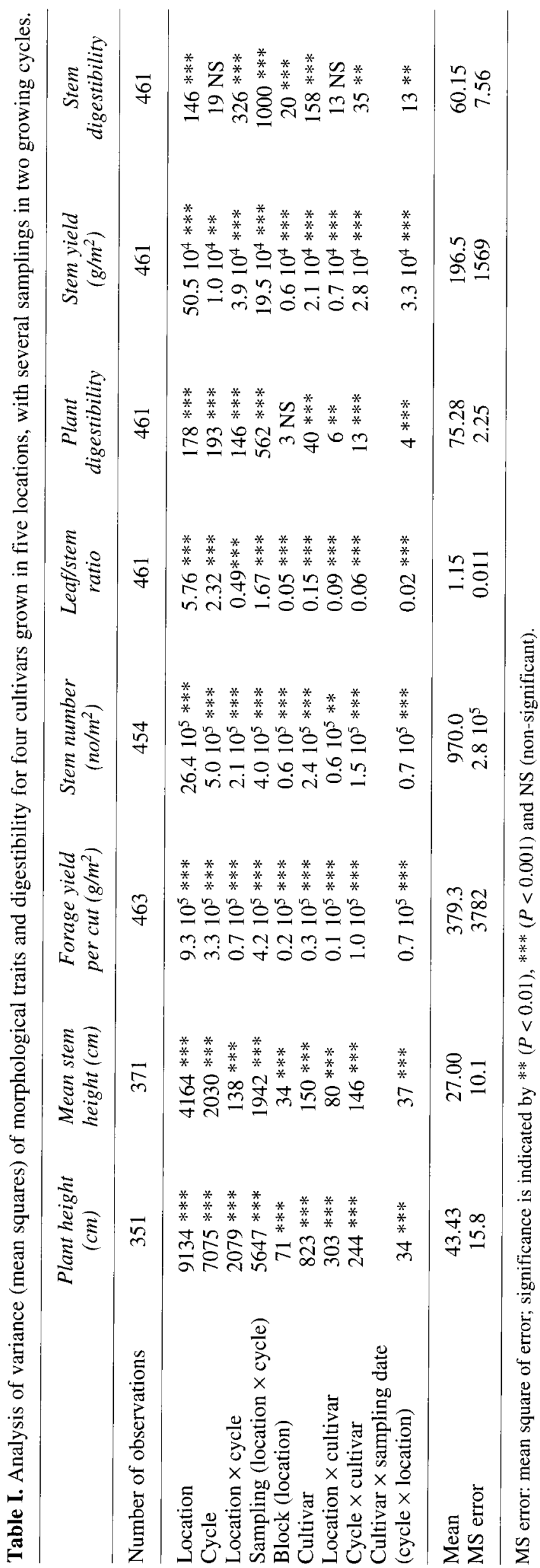


Table II. Phenotypic correlations $r$ (and number of observations) between morphological traits and digestibility, calculated with four cultivars grown in five locations, with several samplings in two growing cycles.

\begin{tabular}{|c|c|c|c|c|c|c|c|}
\hline & $\begin{array}{c}\text { Plant } \\
\text { digestibility }\end{array}$ & Forage yield & $\begin{array}{l}\text { Leaf/stem } \\
\text { ratio }\end{array}$ & Stem yield & $\begin{array}{c}\text { Stem } \\
\text { digestibility }\end{array}$ & $\begin{array}{l}\text { Plant height } \\
\quad \text { height }\end{array}$ & Mean stem \\
\hline Forage yield & $\begin{array}{c}-0.808 \\
(124)\end{array}$ & & & & & & \\
\hline Leaf/stem ratio & $\begin{array}{l}0.868 \\
(124)\end{array}$ & $\begin{array}{c}-0.851 \\
(124)\end{array}$ & & & & & \\
\hline Stem yield & $\begin{array}{c}-0.839 \\
(124)\end{array}$ & $\begin{array}{l}0.976 \\
(124)\end{array}$ & $\begin{array}{c}-0.905 \\
(124)\end{array}$ & & & & \\
\hline Stem digestibility & $\begin{array}{l}0.906 \\
(124)\end{array}$ & $\begin{array}{c}-0.627 \\
(124)\end{array}$ & $\begin{array}{l}0.620 \\
(124)\end{array}$ & $\begin{array}{c}-0.602 \\
(124)\end{array}$ & & & \\
\hline Plant height & $\begin{array}{c}-0.902 \\
(96)\end{array}$ & $\begin{array}{c}0.913 \\
(96)\end{array}$ & $\begin{array}{c}-0.934 \\
(96)\end{array}$ & $\begin{array}{c}0.951 \\
(96)\end{array}$ & $\begin{array}{c}-0.649 \\
(96)\end{array}$ & & \\
\hline Mean stem height & $\begin{array}{c}-0.879 \\
(124)\end{array}$ & $\begin{array}{l}0.875 \\
(124)\end{array}$ & $\begin{array}{l}-0.921 \\
(124)\end{array}$ & $\begin{array}{l}0.907 \\
(124)\end{array}$ & $\begin{array}{c}-0.671 \\
(124)\end{array}$ & $\begin{array}{c}0.961 \\
(96)\end{array}$ & \\
\hline Number of stems & $\begin{array}{l}0.433 \\
(124)\end{array}$ & $\begin{array}{c}-0.279 \\
(124)\end{array}$ & $\begin{array}{l}0.481 \\
(124)\end{array}$ & $\begin{array}{c}-0.341 \\
(124)\end{array}$ & $\begin{array}{l}0.311 \\
(124)\end{array}$ & $\begin{array}{c}-0.463 \\
(96)\end{array}$ & $\begin{array}{c}-0.565 \\
(124)\end{array}$ \\
\hline
\end{tabular}

Table III. Parameters ( $\pm \mathrm{SE})$ of the equation: digestibility $=a+b *$ yield, for the four cultivars and the five locations and global equation.

\begin{tabular}{lccc}
\hline & $a$ & $b$ & $R^{2}$ \\
\hline Europe & $85.99 \pm 1.40$ & $-0.02692 \pm 0.0031$ & 0.72 \\
Lodi & $85.18 \pm 1.51$ & $-0.02922 \pm 0.0038$ & 0.67 \\
Maya & $84.80 \pm 1.43$ & $-0.02465 \pm 0.0032$ & 0.66 \\
63-28P & $84.83 \pm 1.44$ & $-0.02401 \pm 0.0035$ & 0.62 \\
& & & 0.81 \\
Cappelle & $85.73 \pm 1.21$ & $-0.03037 \pm 0.0028$ & 0.36 \\
Connantre & $85.77 \pm 4.43$ & $-0.02168 \pm 0.0078$ & 0.74 \\
Verneuil & $88.65 \pm 1.67^{*}$ & $-0.03306 \pm 0.0036^{*}$ & 0.91 \\
Lusignan & $88.01 \pm 1.07^{* * *}$ & $-0.03949 \pm 0.0032^{* *}$ & 0.29 \\
Montpellier & $81.76 \pm 1.48^{*}$ & $-0.0164 \pm 0.0047^{*}$ & 0.63 \\
\hline Global & $84.99 \pm 0.71$ & $-0.02565 \pm 0.0017$ &
\end{tabular}

$*, * *, * * *$ Significantly different from global regression at $5,1,0.1 \%$ respectively.

alfalfa, there has been little assessment of traits related to digestibility or leaf/stem ratio. Previous work demonstrated a decrease in leaf/stem ratio, stem digestibility and whole plant digestibility during growth (Terry and Tilley, 1964; Mowat et al, 1964; Albrecht et al, 1987). During growth, stems grow but few new leaves are established, so the leaf/stem ratio decreases. Lignification during stem growth induces a decrease in stem digestibility. A combination of decreases in leaf/stem ratio and stem digestibility results in a decrease in plant digestibility. The effect of location on digestibility raises several questions. As we measured dry matter digestibilities and not organic matter digestibilities, the mineral composition of the soils can be involved in location effect through modification of ash content. Lemaire et al (1989) and Deetz et al (1996) observed higher digestibility or lower fibre content in plants subjected to water stress. Vough and Marten (1971) showed that plant digestibility decreases even though leaf percentage increases, for plants cultivated at high temperature compared to plants cultivated at low temperature. However, in our experiment, we did not observe an increasing average digestibility under cooler conditions. Moreover, the regressions between digestibility and yield were different from one location to another. Digestibility decreased less quickly at Montpellier than the other locations. The harvest dates may have corresponded to younger phenological stages, as leaf/stem ratios at the beginning of flowering were 1.11 and 1.27 at Montpellier in 


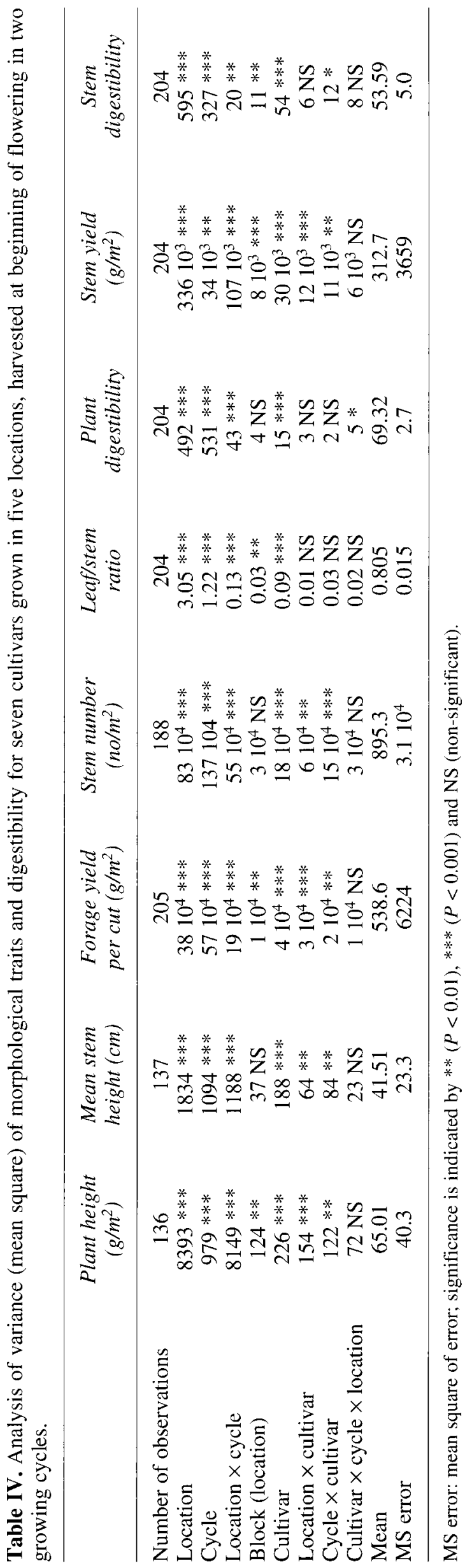




\section{Europe}
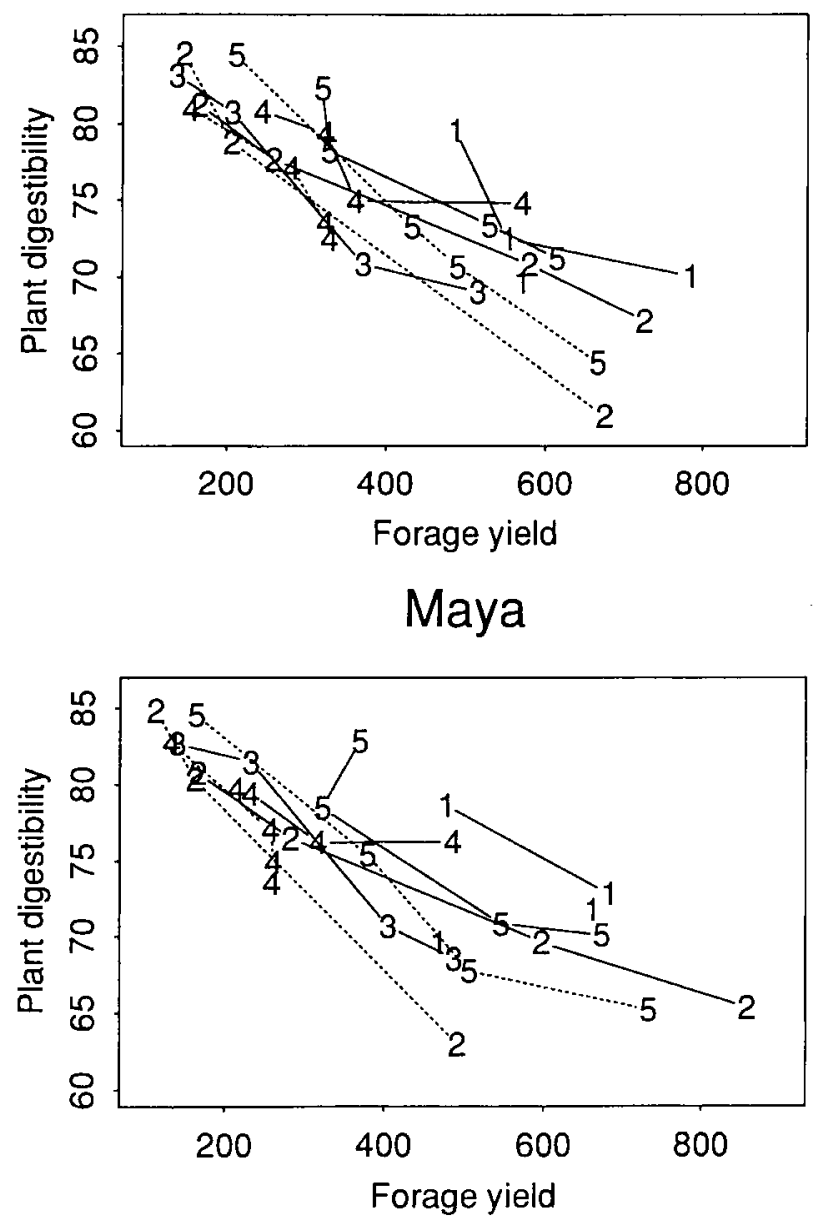

Lodi
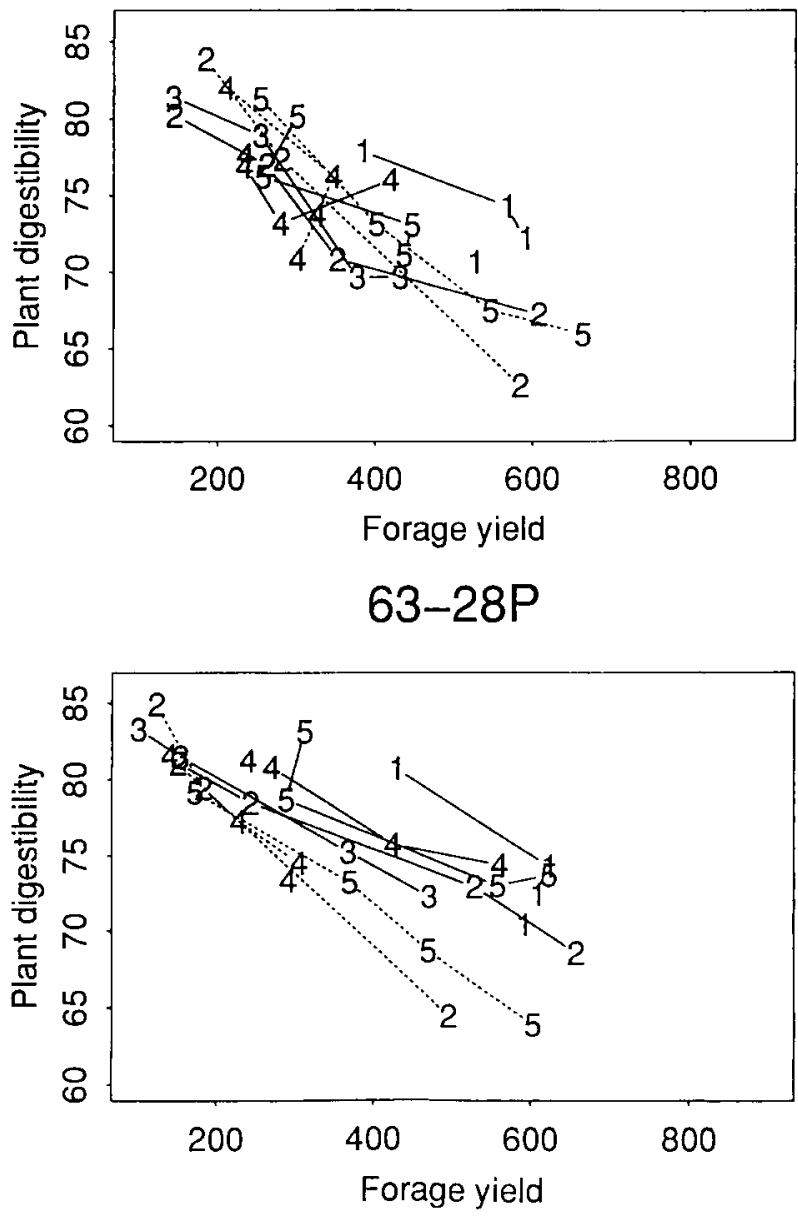

Fig 1. Relationship between forage yield $\left(\mathrm{g} / \mathrm{m}^{2}\right)$ and whole plant digestibility $(\%)$, for four cultivars in five locations and two regrowth periods (1: Connantre; 2: Cappelle; 3: Lusignan; 4: Montpellier; 5: Verneuil; ___ first cycle, - - . - : second cycle).

Table V. Phenotypic correlations $r$ (and number of values) between morphological traits and digestibility, calculated with seven cultivars grown in five locations, harvested at beginning of flowering in two growing cycles.

\begin{tabular}{|c|c|c|c|c|c|c|c|}
\hline & $\begin{array}{c}\text { Plant } \\
\text { digestibility }\end{array}$ & Forage yield & $\begin{array}{l}\text { Leaf } / \text { stem } \\
\text { ratio }\end{array}$ & Stem yield & $\begin{array}{c}\text { Stem } \\
\text { digestibility }\end{array}$ & $\begin{array}{l}\text { Plant height } \\
\quad \text { height }\end{array}$ & $\begin{array}{l}\text { Mean stem } \\
\text { height }\end{array}$ \\
\hline Forage yield & $\begin{array}{l}\text { NS } \\
\text { (57) }\end{array}$ & & & & & & \\
\hline Leaf/stem ratio & $\begin{array}{c}0.760 \\
(57)\end{array}$ & $\begin{array}{c}-0.487 \\
(57)\end{array}$ & & & & & \\
\hline Stem yield & $\begin{array}{c}-0.445 \\
(57)\end{array}$ & $\begin{array}{c}0.932 \\
(57)\end{array}$ & $\begin{array}{c}-0.748 \\
(57)\end{array}$ & & & & \\
\hline Stem digestibility & $\begin{array}{c}0.638 \\
(57)\end{array}$ & $\begin{array}{c}0.296 \\
(57)\end{array}$ & $\begin{array}{l}\text { NS } \\
(57)\end{array}$ & $\begin{array}{l}\text { NS } \\
(57)\end{array}$ & & & \\
\hline Plant height & $\begin{array}{c}-0.839 \\
(39)\end{array}$ & $\begin{array}{c}0.754 \\
(39)\end{array}$ & $\begin{array}{c}-0.846 \\
(39)\end{array}$ & $\begin{array}{c}0.893 \\
(39)\end{array}$ & $\begin{array}{l}\text { NS } \\
(39)\end{array}$ & & \\
\hline Mean stem height & $\begin{array}{c}-0.701 \\
(48)\end{array}$ & $\begin{array}{c}0.602 \\
(48)\end{array}$ & $\begin{array}{c}-0.753 \\
(48)\end{array}$ & $\begin{array}{c}0.739 \\
(48)\end{array}$ & $\begin{array}{l}\text { NS } \\
(48)\end{array}$ & $\begin{array}{c}0.905 \\
(33)\end{array}$ & \\
\hline Number of stems & $\begin{array}{c}0.288 \\
(57)\end{array}$ & $\begin{array}{l}\text { NS } \\
(57)\end{array}$ & $\begin{array}{c}0.423 \\
(57)\end{array}$ & $\begin{array}{l}\text { NS } \\
(57)\end{array}$ & $\begin{array}{l}\text { NS } \\
(57)\end{array}$ & $\begin{array}{c}-0.366 \\
(39)\end{array}$ & $\begin{array}{c}-0.492 \\
(48)\end{array}$ \\
\hline
\end{tabular}

All the correlations were significant except those marked NS. 
Table VI. Adjusted means of plant digestibility, stem digestibility, leaf/stem ratio and forage yield per cut $\left(\mathrm{g} / \mathrm{m}^{2}\right)$ in analysis of variance, for seven cultivars grown in five locations, and harvested at beginning of flowering in two growing cycles.

\begin{tabular}{lcccc}
\hline & \multirow{2}{*}{$\begin{array}{c}\text { Plant } \\
\text { digestibility }\end{array}$} & $\begin{array}{c}\text { Stem } \\
\text { digestibility }\end{array}$ & \multicolumn{2}{c}{ Leaf/stem } \\
& ratio & Forage \\
& yield \\
\hline Europe & 68.52 & 54.10 & 0.71 & 586 \\
Julus & 68.24 & 53.55 & 0.70 & 517 \\
Lodi & 69.30 & 52.67 & 0.84 & 486 \\
Luzelle & 68.28 & 52.91 & 0.73 & 536 \\
Maya & 68.96 & 53.83 & 0.77 & 543 \\
Natsuwakaba & 67.73 & 50.02 & 0.82 & 468 \\
63-28P & 70.08 & 54.68 & 0.81 & 522 \\
\hline
\end{tabular}

SE are in table IV.

Table VII. Average plant digestibility and forage yield per cut $\left(\mathrm{g} / \mathrm{m}^{2}\right)$ in each location, for the two cycles studied.

\begin{tabular}{lcccc}
\hline & Cycle & Digestibility & $\begin{array}{c}\text { Forage } \\
\text { yield }\end{array}$ & $\begin{array}{c}\text { Average } \\
\text { temperature }\end{array}$ \\
\hline Connantre & 1 & 71.32 & 675.3 & 10.40 \\
& 2 & 69.35 & 543.4 & 13.92 \\
Cappelle & 1 & 67.06 & 711.6 & 12.05 \\
& 2 & 63.03 & 450.4 & 16.14 \\
Lusignan & 1 & 69.87 & 475.8 & 13.06 \\
Montpellier & 1 & 74.43 & 537.1 & 14.92 \\
& 2 & 72.24 & 312.0 & 20.04 \\
Verneuil & 1 & 70.63 & 585.8 & 11.66 \\
& 2 & 64.38 & 661.2 & 19.34 \\
\hline
\end{tabular}

The average temperature in each location $\times$ cycle was calculated over the last 4 weeks before the last sampling (beginning of flowering of cv Europe).

the first and second cycles and between 0.46 and 0.82 in the other locations on average. The effect of growth cycle on digestibility was already observed by Sanderson and Wedin (1988) and Jarrige (1981). Correlations were found between plant or stem digestibilities, and morphological traits such as height, leaf/stem ratio and forage yield. Lemaire and Allirand (1993) showed a curvilinear regression between yield and digestibility when variations due to growth were considered. Several authors noticed the strong correlation between plant digestibility and leaf/stem ratio (Heinrichs et al, 1969; Jarrige, 1981). The four cultivars studied had similar changes of plant digestibility with dry matter yield during the regrowth period.
At harvest time (beginning of flowering), we observed location, cycle and cultivar effects for all traits. Other authors have found genetic variation for plant digestibility (Allinson et al, 1969) or stem digestibility (Heinrichs et al, 1969; Buxton et al, 1987; Lenssen et al, 1991). Over the nine combinations of locations and cycles, the difference for plant digestibility was 2.5 points between Natsuwakaba and 63-28P. These plant digestibilities were achieved through various combinations of leaf/stem ratio and stem digestibility. Natsuwakaba had a high leaf/stem ratio but a very poor stem digestibility resulting in a poor plant digestibility. 63-28P combined high leaf/stem ratio and high stem digestibility. The other cultivars considered in this study had either a high leaf/stem ratio or a high stem digestibility, resulting in similar plant digestibilities. These results were obtained with the calculation of stem digestibility through plant digestibility and leaf/stem ratio, assuming a constant leaf digestibility. A genetic difference for leaf digestibility has only been reported once (Lenssen et al, 1991), and this was probably due to the presence of one $M$ falcata population. Significant correlation was observed between plant digestibility and stem height, induced by the correlations between leaf/stem ratio and plant height and between plant digestibility and leaf/stem ratio. Height seemed to be the morphological trait most related to digestibility. Correlation between digestibility and yield was not significant. On a range of populations from $M$ sativa complex including ssp falcata and ssp sativa, Julier et al (1996) found a significant relationship between forage yield and stem digestibility, which could be due to the large variations in forage yields due to growth. Other studies showed no correlation or weak correlation between yield and digestibility (Heinrichs et al, 1969; Hill and Barnes, 1977; Sunberg et al, 1983; Coors et al, 1986; Buxton et al, 1987). Digestibility can be improved without significant decrease of forage yield (Demment et al, 1986). Our results showed that the two parameters that contribute to plant digestibility, ie, leaf/stem ratio and stem digestibility, which appeared uncorrelated at harvest time, require further investigation to maximize genetic progress. Forage yields also have to be measured to avoid a shift towards low yielding varieties.

Acknowledgements: We thank the Inra Plant Breeding Station of Montpellier and the plant breeders from 'ACVF Luzerne' who contributed to this study, C Ecalle, A Porcheron, A Gilly for efficient technical work, M Lila and V Furstoss for chemical analysis. 


\section{REFERENCES}

Albrecht KA, Wedin WF, Buxton DR (1987) Cell-wall composition and digestibility of alfalfa stems and leaves. Crop Sci 27, 735-741

Allinson DW, Elliot FC, Tesar MB (1969) Variations in nutritive value among species of the Medicago genus as measured by laboratory techniques. Crop Sci 9, 634-637

Andrieu J, Demarquilly C, Sauvant D (1988) Tables de la valeur nutritive des aliments. In: Alimentation des bovins, ovins et caprins (R Jarrige, ed), Inra, Paris, 356-443

Buxton DR, Hornstein JS, Marten GC (1987) Genetic variation for forage quality of alfalfa stems. Can $J$ Plant Sci 67, 1057-1067

Carter PR, Sheaffer CC (1983) Alfalfa response to soil water deficits. I. Growth, forage quality, yield, water use, and water use efficiency. Crop Sci 23, 669-675

Coors JG, Lowe CC, Murphy RP (1986) Selection for improved nutritional quality of alfalfa forage. Crop Sci 26, 843-848

Deetz DA, Jung HG, Buxton DR (1996) Water-deficit effects on cell-wall composition and in vitro degradability of structural polysaccharides from alfalfa stems. Crop Sci 36, 383-388

Demment MW, Teuber LR, Bourque DP, Phillips DA (1986) Changes in forage quality of improved populations. Crop Sci 26, 1137-1143

Émile JC, Traineau R (1993) Effet de la variabilité génétique sur la digestibilité in vivo de la luzerne. Fourrages 134, 251-254

Émile JC, Barrière Y, Mauriès M (1996) Effects of maize and alfalfa genotypes on dairy cows performances. Ann Zootech 45, 17-27

Émile JC, Mauriès M, Allard G, Guy P (1997) Genetic variation in the feeding value of alfalfa genotypes evaluated from experiments with dairy cows. agronomie 17, 119-125

Heinrichs DH, Troelsen JE, Warder FG (1969) Variation of chemical constituents and morphological characters within and between alfalfa populations Can J Plant Sci 49, 293-305

Hills RR Jr, Barnes RF (1977) Genetic varibility for chemical composition of alfalfa. II. Yield and traits associated with digestibility. Crop Sci 17, 948-952

Hintz RW, Albrecht KA (1991). Prediction of alfalfa chemical composition from maturity and plant morphology. Crop Sci 31, 1561-1565
Jarrige R (1981) Constituants glucidiques des fourrages: variations, digestibilité et dosage. In: Prévision de la valeur nutritive des aliments des ruminants (C Demarquilly, ed), Inra Publications, Versailles, 13-40

Julier B, Guy P, Castillo-Acuna C, Caubel G, Ecalle C, Esquibet $M$, Furstoss V, Huyghe C, Lavaud C, Porcheron A, Pracros P, Raynal G (1996) Genetic variability for pest resistance and forage quality in perennial diploid and tetraploid lucerne populations (Medicago sativa L). Euphytica 91, 241-250

Kalu BA, Fick GW (1983) Morphological stage of development as a predictor of alfalfa herbage quality. Crop Sci 23, 1167-1172

Lemaire G, Allirand JM (1993) Relation entre croissance et qualité de la luzerne: interaction génotypemode d'exploitation. Fourrages 134, 183-198

Lemaire G, Durand JL, Lila M (1989) Effet de la sécheresse sur la digestibilité in vitro, la teneur en ADF et la teneur en azote de la luzerne (Medicago sativa $\mathrm{L}$ ) agronomie 9, 841-848

Lenssen AW, Sorensen EL, Posler GL, Harbers LH (1991) Basic alfalfa germplasms differ in nutritive content of forage Crop Sci 31, 293-296

Lila M, Barrière Y, Traineau R (1986) Mise au point et étude d'un test enzymatique de la digestibilité de fourrages pauvres ou riches en amidon. agronomie 6, 285-291

Mowat DN, Fulkerson RS, Tossel WE, Winch JE (1965) The in vitro digestibility and protein content of leaf and stem portions of forages. Can J Plant Sci 45, 321-331

Onstad DW, Fick GW (1983) Predicting crude protein, in vitro true digestibility, and leaf proportion in alfalfa herbage. Crop Sci 23, 961-964

Sanderson MA, Wedin WF (1988) Cell wall composition of alfalfa stems at similar morphological stage and chronological age during spring growth and summer regrowth. Crop Sci 28, 342-347

Sunberg JE, Murphy RP, Lowe CC (1983) Selection for fiber and protein concentration in a diverse alfalfa population. Crop Sci 23, 11-14

Terry RA, Tilley JMA (1964) The digestibility of the leaves and stems of perennial ryegrass, cocksfoot, timothy, tall fescue, lucerne and sainfoin, as measured by an in vitro procedure. $J$ Br Grassland Soc $19,363-372$

Vough LR, Marten GC (1971) Influence of soil moisture and ambient temperature on yield and quality of alfalfa forage. Agron J 63, 40-42 